psychological development of children exposed to ordinary environmental lead levels. It opens, appropriately enough, with a discussion of the methodological difficulties of interpreting the numerous studies which attempt to identify the disease-exposure relationship. It is unfortunate that most of these studies use $\mathrm{PbB}$ as the only exposure index, although the most important study in America does include dentine lead as a cummulative index. The warning against equating correlations with causal relationships are well taken, and the critical commentary on the conclusions drawn from studies exploring lead-effects on intelligence and behaviour are particularly helpful. Although caution in the interpretation of low-level exposure data is clearly in order, there is no lack of evidence. from epidemiological studies and animal experiments, that massive and moderate exposure produces measurable neurobehavioural effects.

The enduring dilemma surrounding the lead debate is that the threshold of leadrelated disease continues to defy definition. This should surprise no one for it requires a quantitative determination of such multivariate parameters as intelligence. behaviour and learning. But supposing that such a threshold could be translated into an indicator of exposure (for example $\mathrm{PbB}$ or $\mathrm{ZPP}$ levels, vide supra) a second, even more difficult question faces policy makers: what is the fiscal value which society attaches to the elimination of marginal plumbism? In crasser terms, how much is the taxpayer willing to pay, in order to raise the average intelligence of the population by, say. 1 per cent?

It is unfortunate that these tricky issues are rarely touched upon in The Lead Debate. Usually, the authors prefer to remain on the safe technical level and to quote from general conclusions of governmental commission reports. A chapter on real and perceived risk of lead disease compared to other health insults which we are exposed to, together with estimates of their cost of abatement. would have been welcome (c.f. New England Journal of Medicine 1982:1392).

On the other hand. the contributors have collected a lot of extremely useful scientific information which will undoubtedly help to keep the continuing debate about plumbism on a firm scientific footing. They have succeeded in avoiding polemics. albeit at the cost of avoiding novel or controversial approaches. Nevertheless The Lead Debate is an important and useful interdisciplinary review of where we stand in our efforts to unravel the complexities of this ancient environmental hazard.

Dr Josef Eisinger is in the Department of Phrsiology and Biophysics at the Mount Sinai School of Medicine, 5th Alenute and lo()th Street. New York. NY 10029. USA.

\section{Visitors from the past}

\section{Theya Molleson}

Lindow Man: The Body in the Bog. Edited by I.M. Stead, J.B. Bourke and Don Brothwell. British Museum Publications, London:1986. Pp.208. £15.

THE great interest that attaches to any bog body derives not simply from the rarity of such finds but also from the intrinsic nature of the body: it is almost a visitor from the past. Such bodies should tell us more of the life and character of the earlier people. To deduce the age and sex of a body is one thing; but to know something of his clothing and ornaments and to discover the ingredients of his last meal and, above all, to see his face is somehow to perceive the whole anima of his time. I don't think that we should be disappoin- one of the most significant bog findings in Britain and the greatest challenge to archaeological conservation. Within days the police moved out, the hospital wanted the body removed and the conservationists were asked to take over. They were expected to prevent any deterioration of the body while allowing endless study, photography, sampling and dissection. And all they knew from previous experience was what not to do. By a conscientious and didactic approach it does seem that Lindow Man has been preserved for posterity.

The volume, Lindow Man, presents the progress reports of the wide range of exploratory studies - from identification of the surrounding peat and of the pollen, cereals and parasites in the stomach to interpretation of the context both geographic and cultural. Some papers are too clearly hurriedly written; others tend to be discursive for want of factual evidence. It is surprising how little appears to be known of our Celtic heritage.

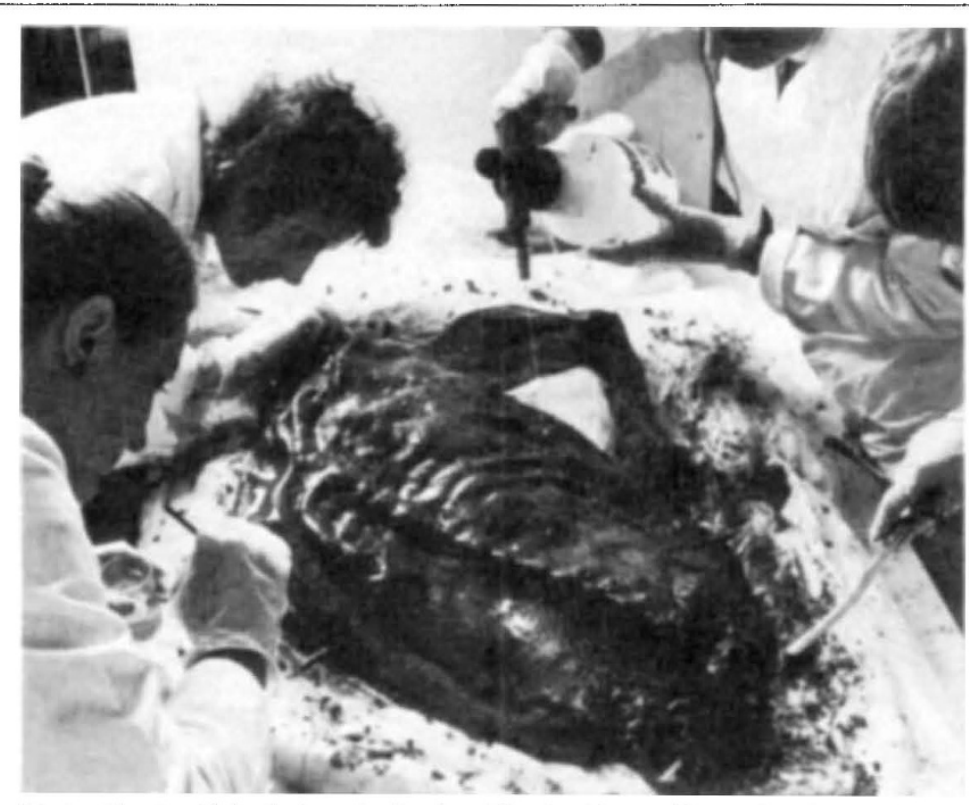

Lindow Man has his back cleaned, taken from The Bog Man and the Archaeology of People (British Museum Publications. Pbk t5.95). In this book, Don Brothwell gives a briefer, less technical account of the Lindow project. Lindow Man is also on display at the British Museum in London. together with the results of the research programme, as part of the exhibition Archaeology in Britain which runs until 15 February 1987.

ted when our expectations are but inadequately realised. Lindow Man has been thoroughly studied but has yet to tell his full story and, not least, to declare his age.

Enormous credit must go to Rick Turner, the county archaeologist for Cheshire, where Lindow Man was discovered in 1984 . He was able immediately to appreciate the archaeological potential that lay in just a fold of skin exposed in the section at the peat cutting. He even managed to convince all concerned that the correct procedure then was to delimit the area of the body, if body there was; to cut it out and crate it for removal to the local mortuary. At this stage the investigation was still a police matter, and not
Concepts of sacrificial ritual emanating from the bog finds in Europe have dominated the approach to the study of Lindow Man. Several workers have found it hard to view their data independently of these theories so that the final interpretation tends to be prejudiced. Yet the information as presented is open to other constructs than that of a ritual killing on the lines of the Danish Bog burials. And that is the advantage of the presentation of the independent studies in detail and in one volume. Readers can make up their own minds.

Theya Molleson is in the Department of Palaeo. entology. British Museum (Natural History), London SW7 SBD. UK. 